\title{
Dietary modification of inflammation with lipids
}

\author{
Philip C. Calder \\ Institute of Human Nutrition, University of Southampton, Bassett Crescent East, Southampton SO16 7PX, UK
}

\begin{abstract}
The $n-3$ polyunsaturated fatty acids (PUFA) eicosapentaenoic acid (EPA) and docosahexaenoic acid (DHA) are found in high proportions in oily fish and fish oils. The $n-3$ PUFA are structurally and functionally distinct from the $n-6$ PUFA. Typically, human inflammatory cells contain high proportions of the $n-6$ PUFA arachidonic acid and low proportions of $n-3$ PUFA. The significance of this difference is that arachidonic acid is the precursor of 2-series prostaglandins and 4-series leukotrienes, which are highly-active mediators of inflammation. Feeding fish oil results in partial replacement of arachidonic acid in inflammatory cell membranes by EPA. This change leads to decreased production of arachidonic acid-derived mediators. This response alone is a potentially beneficial anti-inflammatory effect of $n$-3 PUFA. However, $n$-3 PUFA have a number of other effects which might occur downstream of altered eicosanoid production or might be independent of this activity. For example, animal and human studies have shown that dietary fish oil results in suppressed production of pro-inflammatory cytokines and can decrease adhesion molecule expression. These effects occur at the level of altered gene expression. This action might come about through antagonism of the effects of arachidonic acid-derived mediators or through more direct actions on the intracellular signalling pathways which lead to activation of transcription factors such as nuclear factor kappa B (NFKB). Recent studies have shown that $n$-3 PUFA can down regulate the activity of the nuclear transcription factor NFKB. Fish oil feeding has been shown to ameliorate the symptoms in some animal models of chronic inflammatory disease and to protect against the effects of endotoxin and similar inflammatory challenges. Clinical studies have reported that oral fish oil supplementation has beneficial effects in rheumatoid arthritis and among some patients with asthma, supporting the idea that the $n-3$ PUFA in fish oil are antiinflammatory. There are indications that inclusion of $n-3$ PUFA in enteral and parenteral formulas might be beneficial to patients in intensive care or post-surgery.
\end{abstract}

Fatty acids: Fish oil: Eicosanoids: Cytokines: Inflammation

\section{Inflammation in health and disease}

Inflammation is the body's immediate response to infection or injury. It is typified by redness, swelling, heat and pain. These characteristic responses occur as a result of increased blood flow, increased permeability across blood capillaries which permits large molecules (e.g. complement, antibodies, cytokines) to leave the bloodstream and cross the endothelial wall, and increased movement of leucocytes from the bloodstream into the surrounding tissue. Inflammation functions to begin the immunological process of elimination of invading pathogens and toxins, and to repair damaged tissue. These responses must be ordered and controlled. Four interconnected proteolytic cascade systems present in the blood are activated; these systems are the coagulation, kinin, fibrinolytic and complement cascades.
The role of the coagulation system is to prevent bleeding and to prevent pathogens from entering damaged vessels. The fibrinolytic system functions to remove blood clots (i.e. to antagonise the coagulation system). The kinins are inflammatory mediators such as bradykinin which is responsible for inducing pain, increasing vascular permeability and causing vasodilation. The complement system forms a link between the other three cascades and the immunological response to infection and injury. Products of complement activation can increase vascular permeability, and can trigger mast cells to release histamine resulting in vasodilation and promotion of chemotaxis of leucocytes towards the site of injury. The movement of cells into the inflammatory or infected site is induced by the up-regulation of adhesion molecules such as intercellular adhesion molecule1 (ICAM-1), vascular cell adhesion molecule-1 (VCAM-1)

\footnotetext{
Abbreviations: COX, cyclo-oxygenase; DHA, docosahexaenoic acid; EPA, eicosapentaenoic acid; ICAM-1, intercellular adhesion molecule-1; IFN, interferon; IאB, inhibitory subunit of NFKB; IL, interleukin; LPS, lipopolysaccharide; LT, leukotriene; NFkB, nuclear factor kappa B; MCT, medium-chain triacylglycerols; PG, prostaglandin; PPAR, peroxisome proliferator-activated receptor; PUFA, polyunsaturated fatty acids; TNF, tumour necrosis factor; TX, thromboxane; VCAM-1, vascular cell adhesion molecule-1.

Corresponding author: Professor P. C. Calder, fax +44 238059 4383, email pcc@ soton.ac.uk
} 
and E-selectin on the surface of endothelial cells, allowing leucocyte binding and subsequent diapedesis. The earliest cells appearing at inflamed sites are granulocytes, with monocytes and/or macrophages and lymphocytes appearing later. Granulocytes, monocytes and macrophages are involved in pathogen killing, in clearing up cellular and tissue debris, and in tissue repair. Helper $\mathrm{T}$ lymphocytes act to regulate monocyte and/or macrophage, natural killer cell, and B lymphocyte activity. Other lymphocytes aid in the elimination of pathogens (e.g. through the activity of cytotoxic $\mathrm{T}$ lymphocytes and the production of antibodies by B lymphocytes). Acute inflammation is the term applied to the early vascular and cellular responses (i.e. up to and including granulocyte infiltration), while chronic inflammation is the term applied to the later cellular events involving monocytes and/or macrophages and lymphocytes. The activity of these cells is induced by certain triggers. One important exogenous trigger is bacterial endotoxin (also known as lipopolysaccharide (LPS)), a component of the cell wall of Gram-negative bacteria. LPS can trigger complement activation (resulting in vasodilation and increased vascular permeability), coagulation, fibrinolysis and the kinin cascade. LPS can directly activate monocytes and macrophages inducing them to produce cytokines such as: tumour necrosis factor (TNF)- $\alpha$, interleukin (IL)- 1 , IL-6 and IL-8; eicosanoids, such as prostaglandin (PG) $\mathrm{E}_{2}$; NO; matrix metalloproteinases; other mediators. LPS also induces adhesion molecule expression on the surface of endothelial cells and leucocytes. Histamine, peptides produced by the complement, coagulation and kinin systems, cytokines and eicosanoids are all endogenous mediators of inflammation. The cytokines produced by monocytes and macrophages also serve to regulate the whole-body response to infection and injury (Fig. 1); for example, they will act on the liver to promote acute-phase protein synthesis, on skeletal muscle and adipose tissue to promote proteolysis and lipolysis respectively (this process is believed to be the body's way of providing fuels to the immune system), and on the brain to reduce appetite and induce fever (Fig. 1). These cytokines will also interact with

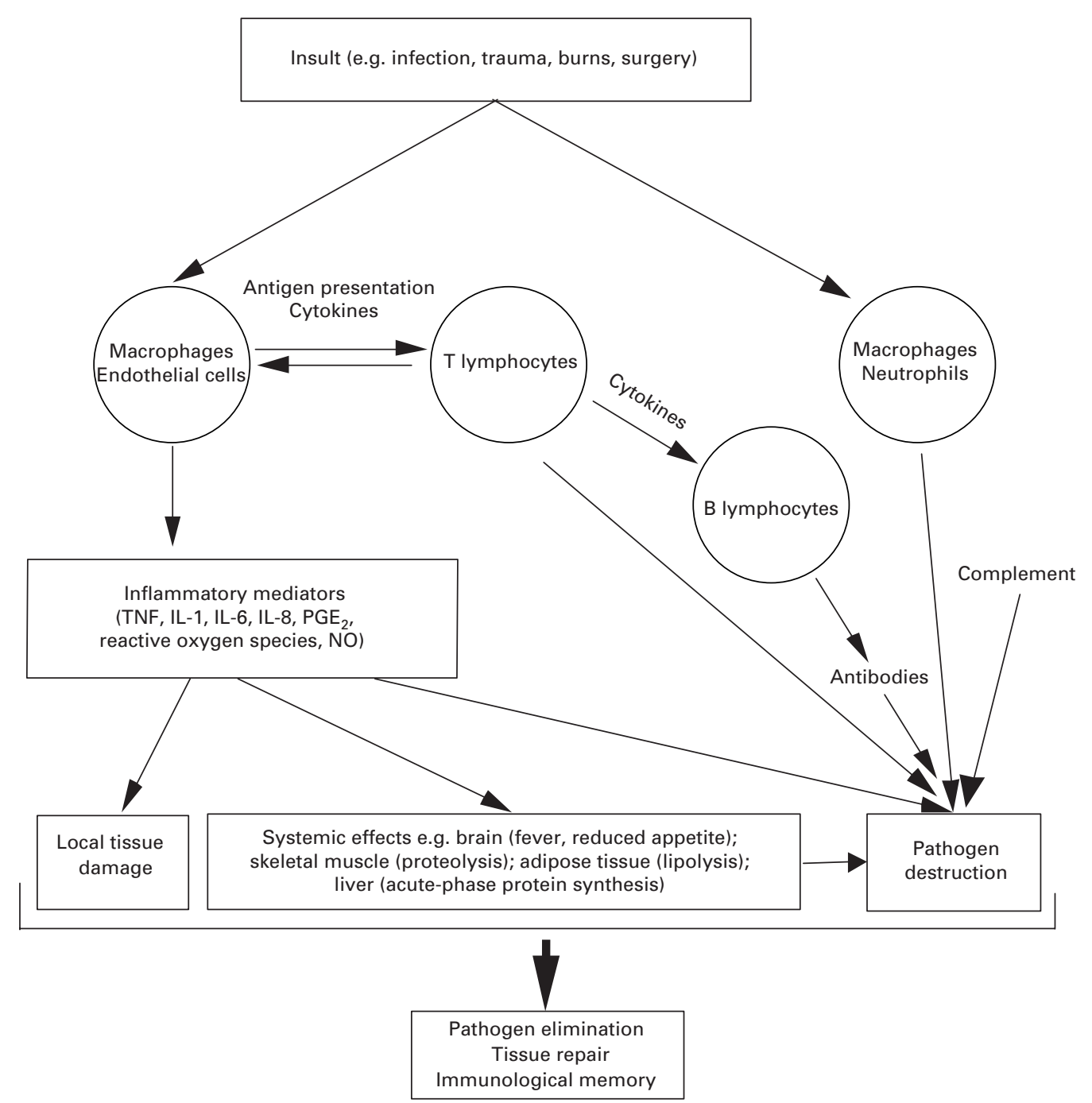

Fig. 1. The interrelationship between components of the innate and acquired immune responses. IL, interleukin; PG, prostaglandin; TNF, tumour necrosis factor. 
T lymphocytes. Antigen-presenting cells, which include activated monocytes and macrophages, will present antigen to T lymphocytes, and so the acquired immune response will be triggered (Fig. 1). Now there will be a cell-mediated response to the antigen. $\mathrm{T}$ lymphocytes will produce cytokines (e.g. interferon (IFN)- $\gamma$ ) which will regulate the activity of the cells involved in the innate response (monocytes, macrophages, natural killer cells), promote the proliferation of $\mathrm{B}$ and $\mathrm{T}$ lymphocytes and promote antibody production by B lymphocytes. By virtue of the integrated innate and acquired responses the source of the antigen should be eliminated and a component of immunological memory will remain (Fig. 1).

Thus, inflammation and the inflammatory response are part of the normal innate immune response. However, when inflammation occurs in an uncontrolled manner disease ensues. High levels of TNF- $\alpha$, IL-1 $\beta$ and IL-6 are particularly destructive. Chronic overproduction of TNF- $\alpha$ and IL-1 may cause muscle wasting and loss of bone mass. TNF- $\alpha$, IL-1 and IL-6 are implicated in causing some of the pathological responses which occur in endotoxic shock, and in adult respiratory distress syndrome and chronic inflammatory diseases such as rheumatoid arthritis and inflammatory bowel disease. It is this highly destructive nature of these and other inflammatory mediators which prompted Thomas (1972) to say 'Our arsenals for fighting off bacteria are so powerful, and involve so many different defence mechanisms, that we are more in danger from them than from the invaders. We live in the midst of explosive devices; we are mined'.

\section{Fatty acids and eicosanoids}

\section{The fatty acid composition of inflammatory cells}

Inflammatory and immune cells from laboratory animals consuming a typical laboratory chow and from human subjects consuming a typical Western diet contain a high proportion of the $n-6$ polyunsaturated fatty acid (PUFA) arachidonic acid (20:4n-6) and low proportions of $n-3$ PUFA, especially eicosapentaenoic acid (20:5n-3; EPA; see Calder, 1998, 2001a). The exact proportion of arachidonic acid in human inflammatory cells varies according to cell type and the lipid fraction examined (Gibney \& Hunter, 1993; Sperling et al. 1993). The phospholipids of human mononuclear cells (an approximately 70:20:10 mixture of $\mathrm{T}$ lymphocytes, B lymphocytes and monocytes purified from human blood) contain (\% total fatty acids) 6-10 linoleic acid (18:2n-6), 1-2 dihomo- $\gamma$-linolenic acid (20: $3 n-6)$ and 15-25 arachidonic acid (Yaqoob et al. 2000; Thies et al. 2001). In contrast, the proportions of $n-3$ fatty acids are low; $\alpha$-linolenic acid $(18: 3 n-3)$ is rare and EPA and docosahexaenoic acid (22:6n-3 DHA) comprise only $0 \cdot 1-0.8$ and $2-4 \%$ total fatty acids respectively (Yaqoob et al. 2000; Thies et al. 2001).

EPA and DHA are found in high proportions in oily fish and fish oils. Animal and human studies show that feeding fish oil results in increased proportions of EPA and DHA in inflammatory cell phospholipids (for references, see Calder 1998, 2001a). These fatty acids are incorporated largely at the expense of arachidonic acid (see
Calder 1998, 2001a). Similar effects occur in neutrophils, monocytes, T lymphocytes and B lymphocytes (Gibney \& Hunter, 1993).

\section{Arachidonic acid as an eicosanoid precursor}

The principal functional role for arachidonic acid is as a substrate for synthesis of the family of bioactive mediators known as eicosanoids (PG, thromboxanes (TX), leukotrienes (LT), hydroxy-eicosatetraenoic acids etc.; Fig. 2). In fact, several $\mathrm{C}_{20}$ PUFA are able to serve as precursors of eicosanoids. However, because the membranes of most cells contain large amounts of arachidonic acid, compared with other potential eicosanoid precursors (including EPA), arachidonic acid is usually the principal precursor of eichosanoid synthesis. Arachidonic acid in cell membranes can be mobilised by various phospholipase enzymes, most notably phospholipase $A_{2}$, and the free arachidonic acid can subsequently act as a substrate for the enzymes which synthesise eicosanoids (Fig. 2). Metabolism of arachidonic acid by cyclo-oxygenase (COX) enzymes gives rise to the 2-series PG and TX (Fig. 2). There are two isoforms of COX: COX-1 is a constitutive enzyme; COX-2 is induced in inflammatory cells as a result of stimulation, and is responsible for the markedly elevated production of PG which occurs on cellular activation. There are at least sixteen different 2-series PG, and these PG are formed in a cell-specific manner. For example, monocytes and macrophages produce large amounts of $\mathrm{PGE}_{2}$ and $\mathrm{PGF}_{2}$, neutrophils produce moderate amounts of $\mathrm{PGE}_{2}$ and mast cells produce $\mathrm{PGD}_{2}$. Metabolism of arachidonic acid by the 5-lipoxygenase pathway gives rise to hydroxy and hydroperoxy derivatives (5-hydroxyeicosatetraenoic acid and 5-hydroperoxyeicosatetraenoic acid respectively), and the 4-series LT (LTA $, \mathrm{B}_{4}, \mathrm{C}_{4}, \mathrm{D}_{4}$ and $\mathrm{E}_{4}$; Fig. 2). 5-Lipoxygenase is found in mast cells, monocytes, macrophages and granulocytes.

Eicosanoids are involved in modulating the intensity and duration of inflammatory responses (for reviews, see Kinsella et al. 1990; Lewis et al. 1990; Tilley et al. 2001). The effects of $\mathrm{PGE}_{2}$ and $\mathrm{LTB}_{4}$ have been studied most widely. $\mathrm{PGE}_{2}$ has a number of pro-inflammatory effects, including inducing fever, increasing vascular permeability and vasodilation, and enhancing pain and oedema caused by other agents such as bradykinin and histamine. $\mathrm{PGE}_{2}$ suppresses lymphocyte proliferation and natural killer cell activity, and inhibits production of IL- 2 and IFN- $\gamma$; thus, in these respects $\mathrm{PGE}_{2}$ is immunosuppressive. $\mathrm{PGE}_{2}$ also promotes immunoglobulin $\mathrm{E}$ production by $\mathrm{B}$ lymphocytes; immunoglobulin $\mathrm{E}$ is a mediator of allergic inflammation. $\mathrm{LTB}_{4}$ increases vascular permeability, enhances local blood flow, is a potent chemotactic agent for leucocytes, induces release of lysosomal enzymes, enhances generation of reactive oxygen species, enhances production of TNF- $\alpha$, IL- 1 and IL-6, and inhibits lymphocyte proliferation. In inflammatory conditions increased rates of production of arachidonic acid-derived eicosanoids are found, and elevated levels of these eicosanoids are found in blood and tissues from patients with a variety of inflammatory disorders (Kinsella et al. 1990; Lewis et al. 1990). 


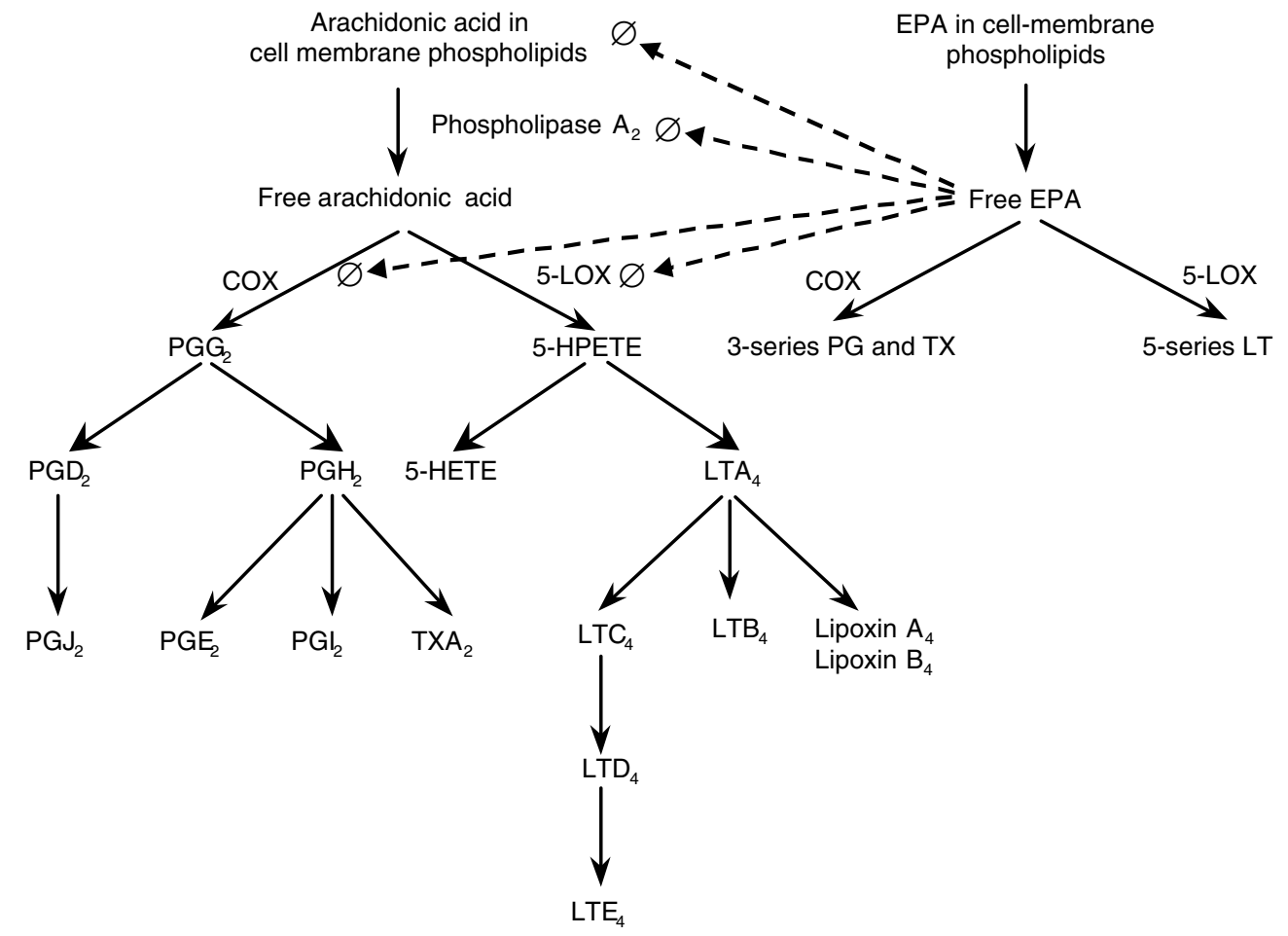

Fig. 2. Synthesis of eicosanoids from arachidonic acid and sites of inhibition by eicosapentaenoic acid. COX, cyclo-oxygenase; EPA, eicosapentaenoic acid; HETE, hydroxyeicosatetraenoic acid; HPETE, hydroperoxyeicosatetraenoic acid; LOX, lipoxygenase; LT, leukotriene; PG, prostaglandin; TX, thromboxane.

\section{Eicosapentaenoic acid as an alternative eicosanoid precursor}

Since feeding animals or human subjects increased amounts of fish oil results in a decrease in the amount of arachidonic acid in the membranes of inflammatory cells, there will be less substrate available for synthesis of eicosanoids from arachidonic acid. Furthermore, EPA inhibits arachidonic acid release from phospholipids by phospholipase $A_{2}$ and competitively inhibits the oxygenation of arachidonic acid by COX (Obata et al. 1999). Thus, fish oil feeding results in a decreased capacity of inflammatory cells to synthesise eicosanoids from arachidonic acid. For example, after fish oil supplementation of the human diet a 50-65\% decrease in $\mathrm{PGE}_{2}$ production by mononuclear cells has been reported (Endres et al. 1989; Meydani et al. 1993; Caughey et al. 1996). Detailed examinations of the effect of dietary fish oil on production of 5-lipoxygenase products were made by Lee et al. (1985) and Sperling et al. (1993). These authors demonstrated that fish oil providing 5.4 or $14.4 \mathrm{~g}$ EPA + DHA/d leads to a 40-70 \% decrease in generation of $\mathrm{LTB}_{4}$, 6-trans $\mathrm{LTB}_{4}, 20$-hydroxy $\mathrm{LTB}_{4}$ and 5-hydroxyeicosatetraenoic acid by neutrophils and monocytes stimulated by various agents including $\mathrm{Ca}$ ionophore, zymosan, and platelet-activating factor.

In addition to inhibiting metabolism of arachidonic acid, EPA is able to act as a substrate for both COX and 5-lipoxygenase (Fig. 2), giving rise to derivatives which have a structure different from those produced from arachidonic acid (i.e. 3-series PG and TX and 5-series LT). Thus, the EPA-induced suppression in the production of arachidonic acid-derived eicosanoids is accompanied by an elevation in the production of EPA-derived eicosanoids. Again this response has been clearly demonstrated by Lee et al. (1985) and Sperling et al. (1993), who showed that dietary fish oil results in significantly increased generation of $\mathrm{LTB}_{5}$, 6-trans $\mathrm{LTB}_{5}$ and 5-hydroxyeicosapentaenoic acid by stimulated neutrophils and monocytes. The eicosanoids produced from EPA are considered to be less biologically potent than the analogues synthesised from arachidonic acid, although the full range of biological activities of these compounds has not been investigated. The best example of differential inflammatory potencies of eicosanoids produced from arachidonic acid and EPA is that of $\mathrm{LTB}_{4} v . \mathrm{LTB}_{5}$. $\mathrm{LTB}_{5}$ is at least 10 -fold less potent as a neutrophil chemoattractant than $\mathrm{LTB}_{4}$, and on this basis can be considered to be less pro-inflammatory. One other aspect of the formation of alternative eicosanoids to those produced from arachidonic acid is that they will share the same receptor on target cells and, therefore, will act to antagonise the arachidonic acid-derived mediators. The reduction in generation of arachidonic acid-derived mediators which accompanies fish oil consumption has led to the idea that fish oil is antiinflammatory.

The isolated perfused rabbit lung has been used as a model to study the pathophysiological effects of arachidonic acid- and EPA-derived eicosanoids. Infusion with Escherichia coli haemolysin was shown to induce vasoconstriction and hypertension, mediated by $\mathrm{TXB}_{2}$, and vascular permeability and/or leakage, mediated by 4-series LT (Grimminger et al. 1995, 1997). Inclusion of free arachidonic acid in the perfusate increased $\mathrm{TXB}_{2}$ and 4-series 
LT generation, arterial pressure and vascular leakage (Grimminger et al. 1995, 1997). In contrast, inclusion of EPA decreased $\mathrm{TXB}_{2}$ and 4-series LT generation, arterial pressure and vascular leakage, and increased generation of $\mathrm{TXB}_{3}$ and 5-series LT (Grimminger et al. 1995). Perfusion of isolated rabbit lungs with a fish oil-containing emulsion markedly attenuated the vascular inflammatory reaction (hypertension) induced by Ca ionophore (Breil et al. 1996). Compared with perfusion with a soyabean oil-rich emulsion, fish oil decreased the concentration of $\mathrm{LTC}_{4}$ in the perfusate by $>50 \%$ and increased the concentration of $\mathrm{LTC}_{5}$ from barely detectable $(<10 \mathrm{pg} / \mathrm{ml})$ to a concentration very similar to that of $\mathrm{LTC}_{4}$ (approximately $150 \mathrm{pg} / \mathrm{ml}$; Breil et al. 1996). These observations indicate that $n-3$ PUFA can inhibit the acute inflammatory responses induced, or at least marked, by production of arachidonic acid-derived eicosanoids.

\section{Anti-inflammatory effects of $\boldsymbol{n - 3}$ polyunsaturated fatty acids other than altered eicosanoid production}

Although their action in antagonising arachidonic acid metabolism is a key anti-inflammatory effect of $n$-3 PUFA, these fatty acids have a number of other anti-inflammatory effects which might occur downstream of altered eicosanoid production or might be independent of this activity. For example, animal and human studies have shown that dietary fish oil results in suppressed production of proinflammatory cytokines and can modulate adhesion molecule expression.

\section{n-3 Polyunsaturated fatty acids and inflammatory cytokine production}

Since inflammatory cytokine production is regulated by arachidonic acid-derived eicosanoids (see RolaPleszczynski \& Stankova, 1992) and since dietary $n-3$ PUFA affect production of these eicosanoids, it is expected that $n$-3 PUFA will affect cytokine production. Indeed this is the case (for reviews, see Calder 1997, 1998, 2001a). Cell-culture studies demonstrated the ability of EPA and DHA to inhibit the production of IL- $1 \beta$ and TNF- $\alpha$ by human monocytes (Sinha et al. 1991; Baldie et al. 1993), and the production of IL- 6 and IL- 8 by human venous endothelial cells (de Caterina et al. 1994; Khalfoun et al. 1997). Culture of a monocytic cell line with EPA or DHA resulted in decreased production of tissue factor, TNF- $\alpha$ and IL-1ß (Chu et al. 1999). Fish oil feeding decreased ex vivo production of TNF- $\alpha$, IL- $1 \beta$ and IL- 6 by rodent macrophages (Billiar et al. 1988; Renier et al. 1993; Yaqoob \& Calder, 1995; Sasaki et al. 2000; Wallace et al. 2000) and splenocytes (Xi et al. 1998). Infusion of fish oil into horses resulted in decreased production of TNF- $\alpha$ by isolated blood monocytes (McCann et al. 2000), while infusion of fish oil into rats decreased production of TNF- $\alpha$ and IL- 6 by blood monocytes (Grimm et al. 1994). Feeding fish oil to mice infected with the murine AIDS virus decreased production of TNF- $\alpha$ and IL-1 $\beta$ by LPS-stimulated splenocytes (Xi et al. 1998). Compared with feeding safflower oil, fish oil feeding resulted in lower peak plasma TNF- $\alpha$ IL- $1 \beta$ and IL-6 concentrations after intraperitoneal injection of LPS in mice (Sadeghi et al. 1999). Furthermore, parenteral nutrition supplemented with fish oil decreased serum TNF- $\alpha$, IL-6, and IL-8 concentrations in burned rats compared with $n-6$ PUFA-rich parenteral nutrition (Hayashi et al. 1998; Tashiro et al. 1998).

Supplementation of the diet of human volunteers with fish oil providing more than $2.4 \mathrm{~g}$ EPA + DHA/d has been shown to decrease production of TNF (Endres et al. 1989; Meydani et al. 1991; Gallai et al. 1993; Caughey et al. 1996), IL-1 (Endres et al. 1989; Meydani et al. 1991; Gallai et al. 1993; Caughey et al. 1996) and IL-6 (Meydani et al. 1991) by mononuclear cells. One other study in which subjects consumed a low-fat diet including oily fish daily (providing $1.2 \mathrm{~g}$ EPA + DHA/d) showed decreased production of TNF, IL-1 and IL-6 (Meydani et al. 1993). Parenteral nutrition supplemented with fish oil has also been shown to affect circulating inflammatory cytokine concentrations; patients received either a medium-chain triacylglycerol (MCT)-long chain triacylglycerol mix or this mix also containing fish oil for $5 \mathrm{~d}$ post-abdominal surgery (Wachtler et al. 1997). Patients received $50 \mathrm{~g}$ fat/d on the first $2 \mathrm{~d}$ and then $100 \mathrm{~g}$ fat/d on days 3, 4 and 5; thus patients in the fish oil group received $3 \mathrm{~g}$ (days 1 and 2) and $6 \mathrm{~g}$ (days 3, 4 and 5) $n-3$ PUFA/d. Serum TNF- $\alpha$ and IL-6 concentrations were lower in patients receiving fish oil (Wachtler et al. 1997).

\section{n-3 Polyunsaturated fatty acids and adhesion molecule expression}

Although it was shown some years ago that culture of murine macrophages with $n-3$ PUFA decreased their ability to bind to various surfaces (Calder et al. 1990), the first demonstration that these fatty acids could affect the expression of adhesion molecules on the cell surface was by de Caterina et al. (1994). These authors showed that culture of human venous endothelial cells with DHA decreased cytokine-induced surface expression of Eselectin, ICAM-1 and VCAM-1 (de Caterina et al. 1994), and impaired the ability of ligand-bearing monocytes to adhere (de Caterina \& Libby, 1996). Although de Caterina et al. (1994) reported that EPA was without effect, Kim et al. (1995) showed that EPA also inhibited LPS-induced expression of these three adhesion molecules on human venous endothelial cells, and again this action had the functional effect of decreasing binding of monocytes. Khalfoun et al. (1996) went on to show that both EPA and DHA could decrease the expression of VCAM-1 on the surface of cytokine-activated human endothelial cells. In another cell-culture study Hughes et al. (1996b) reported that EPA decreased surface expression of ICAM-1 on monocytes stimulated with IFN- $\gamma$.

Studies of dietary fatty acids and adhesion molecule expression are few. Dietary fish oil decreased expression of certain adhesion molecules, including ICAM-1, on the surface of rat lymphocytes (Sanderson et al. 1995a,b; Sanderson \& Calder, 1998a) and murine macrophages (Miles et al. 2000). Supplementing the diet of healthy human subjects with fish oil providing about $1.5 \mathrm{~g} \mathrm{EPA}+$ DHA/d resulted in a lower level of expression of ICAM-1 
on the surface of blood monocytes stimulated ex vivo with IFN- $\gamma$ (Hughes et al. 1996a). Recently, dietary fish intake was found to decrease circulating levels of soluble VCAM-1 in elderly subjects (Miles et al. 2001), but it is not clear if this response represents decreased surface expression of VCAM-1.

\section{Effects of $\boldsymbol{n}-3$ polyunsaturated fatty acids on expression of genes involved in inflammation}

\section{n-3 Polyunsaturated fatty acids and inflammatory gene expression}

Many of the anti-inflammatory effects of $n$-3 PUFA appear to be exerted at the level of altered gene expression. However, these effects have been demonstrated only a limited number of times, and often in artificial in vitro settings, and thus the extent of these effects in vivo is not yet clear. Nevertheless, cell-culture, and animal feeding, studies indicate potentially very potent effects of $n$-3 PUFA on expression of a range of inflammatory genes.

A recent study demonstrated that culturing bovine chondrocytes with $\alpha$-linolenic acid, EPA or DHA markedly decreases cytokine-mediated induction of expression of the COX-2 (but not COX-1), TNF- $\alpha$ and IL- $1 \alpha$ genes (Curtis et al. 2000). The same study investigated the influence of $n-3$ PUFA on the expression of aggrecanase- 1 and -2 genes. Aggrecanase- 1 and -2 degrade cartilage proteoglycan, and their expression in cartilage is up regulated in response to the pro-inflammatory cytokines TNF- $\alpha$ and IL-1. $n-3$ PUFA, but not other fatty acids, inhibited cytokinemediated up-regulation of expression of the aggrecanase-1 and aggrecanase-2 genes, and of aggrecanase activity (Curtis et al. 2000). McCabe et al. (1999) reported that culture of renal carcinoma cells with EPA decreased the level of mRNA for matrix metalloproteinase-2. In an earlier study de Caterina et al. (1994) had demonstrated that the down-regulation of VCAM-1 expression on endothelial cells caused by DHA was exerted at the level of VCAM-1 gene expression, and that this effect was independent of effects on eicosanoid production and on antioxidant status. Culture of murine peritoneal macrophages with DHA, but not with EPA, decreased the level of mRNA for inducible NO synthase after stimulation with LPS and IFN- $\gamma$ (Khair-El-Din et al. 1996). This effect correlated with decreased production of NO, and was due to decreased transcription of the inducible NO synthase gene (Khair-ElDin et al. 1996).

Several animal feeding studies have demonstrated an effect of dietary fish oil on inflammatory gene expression. Inclusion of fish oil in the diet completely abolished mRNA for TNF- $\alpha$, IL-1 $\beta$ and IL- 6 in the kidneys of autoimmune disease-prone mice (Chandrasekar \& Fernandes, 1994). Feeding wild-type mice a fish oil-rich diet decreased the level of IL-1 $\beta$ mRNA in LPS- or phorbol ester-stimulated spleen lymphocytes (Robinson et al. 1996); the lower IL-1 $\beta$ mRNA level was not due to accelerated degradation but to impaired synthesis. Fish oil feeding to mice lowered basal and LPS-stimulated TNF- $\alpha$ mRNA levels in peritoneal macrophages (Renier et al. 1993). Wallace et al. (2001) reported that feeding fish oil to mice resulted in lower levels of IFN- $\gamma$ mRNA in mitogen-stimulated spleen lymphocytes. ICAM-1 mRNA levels were lower in fresh peritoneal macrophages from mice fed fish oil (Miles et al. 2000).

\section{The mechanism(s) by which $n-3$ polyunsaturated fatty acids might down regulate inflammatory gene expression}

Eicosanoids derived from arachidonic acid are able to regulate inflammatory gene expression. Thus, the effects of $n-3$ PUFA described earlier might come about through antagonism of the effects of arachidonic acid-derived mediators. However, at least some (if not all) of these effects seem to occur in an eicosanoid-independent manner (for example, see de Caterina et al. 1994). It is now emerging that $n-3$ PUFA might exert their effects through direct actions on the intracellular signalling pathways which lead to activation of one or more transcription factors such as nuclear factor kappa B (NFkB).

$\mathrm{NF \kappa B}$ plays a role in inducing a range of inflammatory genes including COX-2, ICAM-1, VCAM-1, E-selectin, TNF- $\alpha$, IL-1 $\beta$, IL-6, inducible NO synthase, acute-phase proteins and matrix metalloproteinases in response to inflammatory stimuli (Christman et al. 1998; Chen et al. 1999; Fig. 3). The signalling pathway leading to NFkB activation is becoming better understood (Karin \& Ben-Neriah, 2000; Karin \& Delhase, 2000). NFאB exists as an inactive heterotrimer in the cytosol of resting inflammatory cells; one of the subunits is called inhibitory subunit of NFkB $(\mathrm{I} \kappa \mathrm{B})$. On stimulation, a signalling cascade activates a protein complex known as I $\kappa \mathrm{B}$ kinase. Activated $\mathrm{I} \kappa \mathrm{B}$ kinase phosphorylates I $\mathrm{B}$ on two $\mathrm{N}$-terminal serine residues, thus promoting its dissociation from the rest of the inactive $\mathrm{NF \kappa B}$ trimer. The remaining NFKB heterodimer is rapidly translocated to the nucleus where it binds to response elements in target genes, so regulating their transcription. The phosphorylated I $\mathrm{B}$ undergoes polyubiquination, targeting it for degradation by the $26 \mathrm{~S}$ proteasome. Recent studies have shown that $n$-3 PUFA can down regulate the activity of the nuclear transcription factor NFאB. Xi et al. (2001) reported that feeding mice fish oil resulted in a lower level of NFKB in the nucleus (i.e. activated NFKB) of LPSstimulated spleen lymphocytes compared with feeding maize oil. Infecting the mice with the murine AIDS virus resulted in increased NFKB in the nucleus, but the level was lower in fish oil-fed mice (Xi et al. 2001). The mechanism by which $n$-3 PUFA decreases the activation of NFKB is not clear. However, Chen \& Zhao (2001) report, in an abstract, that incubating human monocytes with EPA decreased LPSinduced activation of $\mathrm{NFKB}$ and that this response was associated with decreased phosphorylation of I $\mathrm{I} B$. This finding suggests an effect of $n-3$ PUFA on the signalling process leading to activation of $\mathrm{I} \kappa \mathrm{B}$ kinase. Ross et al. (1999) reported that incubation of a pancreatic cell line with TNF- $\alpha$ markedly up regulated degradation of $\mathrm{I} \kappa \mathrm{B}$, and that this activity could be totally abolished by previous incubation of the cells with EPA. This effect could be due to inhibition of phosphorylation of $\mathrm{I} \kappa \mathrm{B}$, so preventing it from being targeted for degradation, or to inhibition of the degradation process itself.

A second group of transcription factors currently undergoing scrutiny for their role in inflammation are 


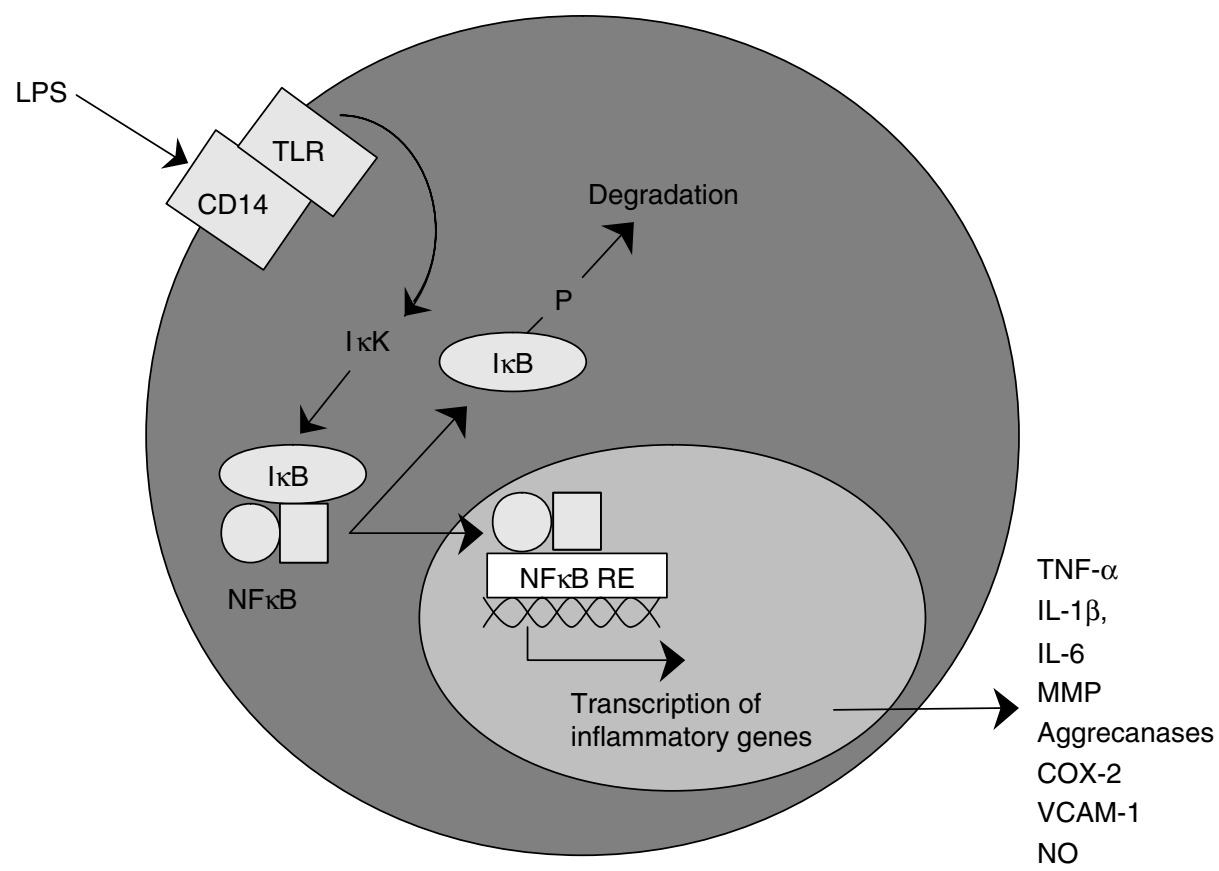

Fig. 3. Outline of the pathway of up-regulation of inflammatory gene expression via nuclear factor kappa B. CD14, cluster of differentiation 14 (the LPS receptor); COX, cyclo-oxygenase; IKB,

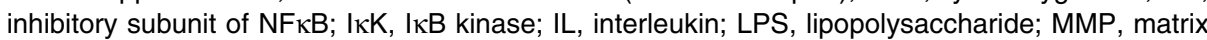
metalloproteinases; NFאB, nuclear factor kappa B; RE, response element; TLR, toll-like receptor; TNF, tumour necrosis factor; VCAM, vascular cell adhesion molecule.

the peroxisome proliferator-activated receptors (PPAR). The main members of this family are PPAR $\alpha$ and PPAR $\gamma$. PPAR $\alpha$ and PPAR $\gamma$ play important roles in liver and adipose tissue respectively (Schoonjans et al. 1996). However, they are also found in inflammatory cells (Chinetti et al. 1998; Ricote et al. 1998). PPAR dimerise with the retinoid-X-receptor to regulate gene expression, and they can bind, and appear to be regulated by, PUFA and eicosanoids (Kliewer et al. 1995; Devchand et al. 1996). PPAR $\alpha$-deficient mice have a prolonged response to inflammatory stimuli (Devchand et al. 1996), suggesting that $\operatorname{PPAR} \alpha$ activation might be 'anti-inflammatory'. More recently, activators of both PPAR $\alpha$ and PPAR $\gamma$ have been shown to inhibit the activation of inflammatory genes, including TNF- $\alpha$, IL-1 $\beta$, IL-6, IL-8, COX-2, VCAM-1, inducible NO synthase, matrix metalloproteinases and acute-phase proteins (Jiang et al. 1998; Poynter \& Daynes, 1998; Ricote et al. 1998; Jackson et al. 1999; Marx et al. 1999; Takano et al. 2000; Wang et al. 2001; Xu et al. 2001). Two mechanisms for the anti-inflammatory actions of PPAR have been proposed (for reviews, see Chinetti et al. 2000; Delerive et al. 2001). The first mechanism is that PPAR might stimulate the breakdown of inflammatory eicosanoids through induction of peroxisomal $\beta$-oxidation. The second mechanism is that PPAR might interfere with or antagonise the activation of other transcription factors, including NFKB. Feeding mice fish oil increases the expression of PPAR $\alpha$ and PPAR $\gamma$ in liver and adipose tissue respectively (Donnellan et al. 2000), and increases the expression of PPAR-inducible genes in these tissues (for example, see Berthou et al. 1995). Although the effect of fish oil on PPAR expression in inflammatory cells has not been reported, these studies suggest that $n$-3 PUFA might act by increasing the level of these anti-inflammatory transcription factors in such cells.

There are a number of other transcription factors which are activated by inflammatory signals and which play a role in expression of inflammatory genes (for a review, see Hwang \& Rhee, 1999). It is possible that $n$-3 PUFA might affect the activation of these factors, but this possibility has not been studied in detail. However, effects of $n$-3 PUFA on signalling processes which lead to activation of various transcription factors including, but not necessarily restricted to, NFKB have been reported. Several early cell signalling events are affected by $n-3$ PUFA. For example, EPA and DHA inhibited the anti-CD3-induced increase in intracellular free $\mathrm{Ca}$ concentration in the JURKAT T-cell line (Chow et al. 1990; Breittmayer et al. 1993), acting by blocking $\mathrm{Ca}$ entry into the cells through a direct effect on receptor-operated Ca channels (Chow et al. 1990). Feeding fish oil was shown to decrease the tyrosine phosphorylation state of phospholipase C- $\gamma$ in rat lymphocytes (Sanderson \& Calder, 1998b) and to reduce the generation of the signalling molecules inositol-1,4,5trisphosphate (Sanderson \& Calder, 1998b), diacylglycerol and ceramide (Jolly et al. 1997) in lymphocytes. EPA and DHA inhibited protein kinase $\mathrm{C}$ activity in rat lymphocytes (May et al. 1993) and peritoneal macrophages (Tappia et al. 1995). Recently, incubation of murine macrophages with 
EPA was found to decrease LPS-induced phosphorylation and activation of mitogen-activated protein kinase (Lo et al. 2000). Thus, a variety of intracellular signalling steps are partly inhibited by the presence of increased amounts of $n-3$ PUFA in cells.

\section{Clinical applications of the anti-inflammatory effects of $n-3$ polyunsaturated fatty acids}

\section{Rheumatoid arthritis: a T-helper 1-type disorder}

Chronic inflammatory diseases such as rheumatoid arthritis are characterised by a dysregulated T-helper 1-type response which drives the production of inflammatory cytokines (e.g. TNF- $\alpha$, IL-1 $\beta$, IL-6, IL-8) and eicosanoids (e.g. $\mathrm{PGE}_{2}, \mathrm{LTB}_{4}$; Feldmann \& Maini, 1999; Panayi, 1999). Synovial biopsies from patients with rheumatoid arthritis contain high levels of TNF- $\alpha$, IL-1 $\beta$, IL- 6 , IL- 8 and granulocyte-macrophage-colony stimulating factor, and synovial cells cultured ex vivo produce TNF- $\alpha$, IL-1 $\beta$, IL-6, IL-8 and granulocyte-macrophage-colony stimulating factor for extended periods of time without additional stimulus (see Feldmann et al. 1996). COX-2 expression is increased in the synovium of patients with rheumatoid arthritis, and in the joint tissues in rat models of arthritis (Sano et al. 1992). $\mathrm{PGE}_{2}, \mathrm{LTB}_{4}$, 5-hydroxyeicosatetraenoic acid and also platelet-activating factor, another phospholipid-derived inflammatory mediator, are found in the synovial fluid of patients with active rheumatoid arthritis (Sperling, 1995). The efficacy of non-steroidal antiinflammatory drugs in rheumatoid arthritis indicates the importance of pro-inflammatory COX-pathway products in the pathophysiology of the disease. It might be expected that up-regulation of adhesion molecules underpins the infiltration of leucocytes into the synovium. Indeed, increased expression of E-selectin, VCAM-1 and ICAM-1 is found in patients with arthritis, and blocking ICAM-1 or VCAM-1 with antibodies reduces leucocyte infiltration into the synovium and synovial inflammation in animal models (for references, see Faull, 1995).

The effects of fish oil on inflammatory eicosanoid and cytokine production and on adhesion molecule expression suggest that it might have a role in prevention and therapy of rheumatoid arthritis and other chronic inflammatory diseases. Dietary fish oil has been shown to have beneficial clinical, immunological and biochemical effects in various animal models of human chronic inflammatory diseases. For example, Leslie et al. (1985) reported that, compared with vegetable oil, feeding mice fish oil delayed the onset and reduced the incidence and severity of type II collageninduced arthritis. It was recently reported that both EPA and DHA suppress streptococcal cell wall-induced arthritis in rats, but that EPA was more effective (Volker et al. 2000); this finding fits with the more potent effects of EPA than DHA on inflammation.

Supplementation of the diet with fish oil has also been shown to decrease the production of IL-1 by mononuclear cells from patients with rheumatoid arthritis (Kremer et al. 1990). Fourteen randomised placebo-controlled doubleblind studies of fish oil in patients with rheumatoid arthritis have been reported. Each of these trials indicates benefits of fish oil which include reduced duration of morning stiffness, reduced number of tender or swollen joints, reduced joint pain, reduced time to fatigue, increased grip strength and decreased use of non-steroidal anti-inflammatory drugs. Details of these trials are reviewed elsewhere (Volker \& Garg, 1996; James \& Cleland, 1997; Geusens, 1998; Calder, 2001 $a, b$; Calder \& Zurier, 2001). In an editorial commentary discussing the use of fish oil in rheumatoid arthritis Cleland \& James (2000) conclude that 'the findings of benefit from fish oil in rheumatoid arthritis are robust', that 'dietary fish oil supplements in rheumatoid arthritis have treatment efficacy', and that 'dietary fish oil supplements should now be regarded as part of the standard therapy for rheumatoid arthritis'.

\section{Asthma: a T-helper 2-type disorder}

Arachidonic acid-derived eicosanoids such as $\mathrm{PGD}_{2}, \mathrm{LTC}_{4}$, $\mathrm{LTD}_{4}$ and $\mathrm{LTE}_{4}$ are produced by the cells that mediate pulmonary inflammation in asthma (e.g. mast cells) and are believed to be the major mediators of asthmatic bronchoconstriction. 4-Series LT have been detected in the blood, bronchoalveolar lavage fluid and urine of asthmatics (Henderson, 1994). In addition to the direct role of eicosanoids as mediators of allergic inflammation, $\mathrm{PGE}_{2}$ regulates $\mathrm{T}$ lymphocyte differentiation, promoting the development of the T-helper 2-type phenotype which underlies allergic inflammation (Betz \& Fox, 1991; Snijdewint et al. 1993; Gold et al. 1994). Thus, a case has been made for increasing the consumption of $n$-3 PUFA by patients with allergic diseases (Hodge et al. 1994; Black \& Sharp, 1997). Indeed, there is increasing epidemiological evidence to support a protective role of long-chain $n-3$ PUFA in allergic disease (for references, see Calder \& Miles, 2000; see also Dunder et al. 2001). A number of trials of fish oil in asthma and related atopic diseases have been performed (for reviews see Knapp, 1995; Calder \& Miles, 2000). Several of these studies reveal limited clinical impact, despite biochemical changes (e.g. reduced 4-series LT production); details of these studies are discussed elsewhere (Knapp, 1995; Calder \& Miles, 2000). In contrast, some studies have shown clinical improvements, at least in some patient groups, and suggest that this type of approach may be useful in conjunction with other drug- and dietbased therapies (see Calder \& Miles, 2000). Broughton et al. (1997) found that 'low' $n$-3 PUFA ingestion resulted in increased methacholine-induced respiratory distress in adult patients with asthma. In contrast, 'high' $n-3$ PUFA ingestion resulted in an improved response in $>40 \%$ of subjects; all measures of respiratory function were markedly improved in this group of patients, who also showed elevated appearance of the EPA-derived 5-series LT in their urine. However, some patients did not respond favourably to the high $n-3$ PUFA intake. This study suggests that there are patients who respond positively to fish oil intervention and patients who are non-responders. This finding suggests that such therapies should be approached cautiously until more is understood about the interaction between fatty acid consumption and disease activity. 


\section{Systemic inflammatory response to injury}

The importance of a hyperinflammatory response, characterised by overproduction of TNF- $\alpha$, IL- $1 \beta$, IL- 6 and IL-8, in the progression of trauma patients towards sepsis is now recognised. Markedly elevated circulating concentrations of these mediators are seen in sepsis (for example, see Cannon et al. 1990; Arnalich et al. 2000), and Vervloet et al. (1998) state that 'these mediators are largely, if not completely, responsible for the clinical signs and symptoms of the septic response to a bacterial infection'. Enhanced production of arachidonic acid-derived eicosanoids such as $\mathrm{PGE}_{2}$ is also associated with trauma and burns (Grbic et al. 1991; Ertel et al. 1992). The inflammatory effects of infection can be mimicked by administration of LPS, which causes an elevation of circulating concentrations of inflammatory cytokines (Tracey et al. 1986; Mathison et al. 1988; Okusawa et al. 1988; Cannon et al. 1990). Laboratory animals can be protected against bacterial- and LPS-induced shock by neutralising these cytokines (Beutler et al. 1985; Tracey et al. 1987; Alexander et al. 1991) and mice deficient in the $55 \mathrm{kDa} \mathrm{TNF}-\alpha$ receptor are resistant to endotoxic shock (Pfeffer et al. 1993). LPS also causes up-regulation of adhesion molecule expression (Kamochi et al. 1999; Raeburn et al. 2001), and deficiency or blocking of VCAM-1 or ICAM-1 induces resistance to LPS (Tang et al. 1995; Kumasaka et al. 1996; Kamochi et al. 1999; Raeburn et al. 2001). The ability of n-3 PUFA to decrease production of inflammatory cytokines and eicosanoids and to decrease adhesion molecule expression suggests that fish oil might be a useful agent to aid the control of endotoxaemia and the so-called systemic inflammatory response syndrome.

Fish oil feeding or infusions enhanced the survival of guinea-pigs following LPS challenge (Mascioli et al. 1988, 1989) and decreased the accompanying metabolic perturbations in guinea-pigs and rats (Hellerstein et al. 1989; Pomposelli et al. 1990; Mulrooney \& Grimble, 1993). Mice fed fish oil and then injected with LPS had lower plasma TNF- $\alpha$, IL- $1 \beta$ and IL-6 concentrations than mice fed safflower oil (Sadeghi et al. 1999), while fish oil-containing parenteral nutrition decreased serum TNF$\alpha$, IL-6 and IL-8 concentrations in burned rats (Hayashi et al. 1998; Tashiro et al. 1998). Total parenteral nutrition using fish oil as the lipid source was found to prevent the LPS-induced reduction in blood flow to the gut and to reduce the number of viable bacteria in mesenteric lymph nodes and liver following exposure to live bacteria (Pscheidl et al. 2000). Fish oil did not, however, decrease bacterial translocation across the gut, and the authors concluded that fish oil must have improved bacterial killing. Fish oil administration before exposure to live pathogens decreased mortality of rats compared with vegetable oil (Barton et al. 1991; Rayon et al. 1997). These studies did not measure inflammatory cytokine levels, but they showed that $\mathrm{PGE}_{2}$ levels were decreased by fish oil (Barton et al. 1991; Rayon et al. 1997). More recently, fish oil infusion after induction of sepsis by caecal ligation and puncture in rats was shown to decrease mortality (and $\mathrm{PGE}_{2}$ production) compared with vegetable oil (Lanza-Jacoby et al. 2001).
An understanding of the inflammatory changes occurring during sepsis and of the anti-inflammatory effects of fish oil combined with the outcome of these animal experiments has prompted clinical studies investigating the influence of fish oil administered either parenterally or enterally. Patients receiving parenteral fish oil following major abdominal surgery had lower serum concentrations of TNF- $\alpha$ and IL-6 than those receiving an MCT-long-chain triacylglycerol mix (Wachtler et al. 1997). This study did not report clinical outcome. In a study reported only in abstract form parenteral administration of an emulsion containing soyabean oil, MCT, olive oil, fish oil and increased amounts of antioxidant vitamins and minerals to patients $(n 19)$ following major abdominal, thoracic or urological surgery enhanced ex vivo $\mathrm{LTB}_{5}$ production by leucocytes and decreased hospital stay (13.4 (SD 2.0) d v. 20.4 (SD 10.0) d compared with standard soyabean oil-based nutrition (Schulzki et al. 1999).

A large number of clinical trials (at least twenty) have been performed in intensive care or surgical patients using enteral formulas containing $n-3$ PUFA. The majority of these trials have used the commercially-available product IMPACT® (Novartis Nutrition, Berne, Switzerland) which contains arginine, yeast RNA and $n-3$ PUFA. Many of these trials report beneficial outcomes, including decreased numbers of infections and infectious or wound complications, decreased severity of infection, decreased need for mechanical ventilation, decreased progression to systemic inflammatory response syndrome and decreased length of intensive care unit and/or total hospital stay. A comprehensive meta-analysis of fifteen randomised controlled studies using IMPACT or Immun-Aid® (McGaw, Irvine, CA, USA; also rich in arginine, RNA and $n-3$ PUFA) has been performed (Beale et al. 1999). This analysis confirmed reductions in infection rate, number of $d$ on a ventilator and length of hospital stay, but not in overall mortality. Few of the studies reviewed measured circulating cytokine levels or ex vivo cytokine production. However, some other studies of IMPACT, not included in the meta-analysis, did so. Plasma IL-6 concentrations were lower in patients given IMPACT following major abdominal surgery than in those receiving standard enteral nutrition (Braga et al. 1996), while preoperative IMPACT decreased post-surgery plasma IL-6 concentrations in patients who underwent surgery to remove malignancies (Braga et al. 1999; Gianotti et al. 1999). More recently, post-cardiac surgery plasma IL-6 concentrations were lower in patients who received IMPACT pre-operatively than in controls (Tepaske et al. 2001). Wu et al. (2001) showed that patients who received an enteral formula containing glutamine, arginine and $n$-3 PUFA post-operatively exhibited lower TNF- $\alpha$ and IL- 6 concentrations. Although each of these observations fits with the predicted effects of $n$ - 3 PUFA and could be used as evidence of their efficacy in the trauma and post-surgery settings, the complex nature of the formulas prevents such a clear interpretation. The effects could be due to any one of the specified nutrients (i.e. arginine, RNA, $n$-3 PUFA) or to the combination of these nutrients. Indeed, the positive outcomes from the use of IMPACT and Immun-Aid have often been used as evidence for the benefit of arginine in these settings. 
One other recent trial performed in patients with moderate and severe acute respiratory distress syndrome has used an enteral preparation apparently differing from the control only in lipid source (\% total lipid (w/w); 32 rapeseed oil $+25 \mathrm{MCT}+20$ borage (Borago officinalis) oil +20 fish oil +3 soyabean lecithin $v .97$ maize oil +3 soyabean lecithin; Gadek et al. 1999). However, as well as the difference in fatty acid composition between the formulas, the $n$-3 PUFA-rich formula contained more vitamin $\mathrm{C}$ and $\mathrm{E}$ than the control and contained $\beta$-carotene, taurine and carnitine, which the control did not. Nevertheless, as the authors state, this study allows the direct assessment of the effects of $n$-3 PUFA plus $\gamma$-linolenic acid (from the borage oil) as a replacement for linoleic acid without the confounding effects of different levels of macronutrients and different types of amino acid. Patients received about $7 \mathrm{~g}$ EPA, $3 \mathrm{~g}$ DHA, $6 \mathrm{~g} \gamma$-linolenic acid, $1 \cdot 1 \mathrm{~g}$ vitamin $\mathrm{C}$, $400 \mathrm{mg}$ vitamin $\mathrm{E}$ and $6.6 \mathrm{mg} \beta$-carotene/d for up to $7 \mathrm{~d}$. The control and experimental groups were well matched and included a number of patients with surgical trauma, sepsis and pneumonia; all patients had respiratory failure and about one-third had failure of at least one other organ system. By $4 \mathrm{~d}$ the numbers of leucocytes and neutrophils in the alveolar fluid had declined in the fish oil $+\gamma$-linolenic acid group and were lower than in the control group. Furthermore, arterial oxygenation and gas exchange were improved in the treatment group. Patients in the treatment group had decreased requirement for supplemental $\mathrm{O}_{2}$, reduced time on ventilation support and shorter length of intensive care unit stay $(12 \cdot 8$ (SE 1.1) d v. 17.5 (SE 1.7 d). Total length of hospital stay also tended to be shorter (29.4 (SE 2.6) d v. 34.6 (SE 3.3) d). Fewer patients in the treatment group developed new organ failure (four of fifty-one $v$. thirteen of forty-seven). Mortality was $19 \%$ in the control group and $12 \%$ in the treatment group, but this difference was not significant. Nevertheless, this study suggests efficacy of $n$-3 PUFA (in combination with $\gamma$-linolenic acid, MCT, antioxidant vitamins, taurine and carnitine) in this group of patients.

\section{Concluding statement}

Inflammation is a component of a range of acute and chronic human diseases, and is characterised by the production of inflammatory cytokines, arachidonic acid-derived eicosanoids, other inflammatory mediators (e.g. platelet-activating factor) and adhesion molecules. n-3 PUFA decrease the production of inflammatory mediators and the expression of adhesion molecules. They act both directly (e.g. by replacing arachidonic acid as an eicosanoid substrate and inhibiting arachidonic acid metabolism) and indirectly (e.g. by altering the expression of inflammatory genes through effects on transcription factor activation). Thus, $n$-3 PUFA are potentially potent anti-inflammatory agents. As such they may be of therapeutic use in a variety of acute and chronic inflammatory settings. Evidence of their clinical efficacy is strong in some settings (e.g. in rheumatoid arthritis), but generally weak in others (e.g. in asthma, in trauma patients).

\section{References}

Alexander HR, Doherty GM, Buresh CM, Venzon DJ \& Norton JA (1991) A recombinant human receptor antagonist to interleukin 1 improves survival after lethal endotoxemia in mice. Journal of Experimental Medicine 173, 1029-1032.

Arnalich F, Garcia-Palomero E, Lopez J, Jimenez M, Madero R, Renart J, Vazquez JJ \& Montiel C (2000) Predictive value of nuclear factor $\mathrm{\kappa B}$ activity and plasma cytokine levels in patients with sepsis. Infection and Immunity 68, 1942-1945.

Baldie G, Kaimakamis D \& Rotondo D (1993) Fatty acid modulation of cytokine release from human monocytic cells. Biochimica et Biophysica Acta 1179, 125-133.

Barton RG, Wells CL, Carlson A, Singh R, Sullivan JJ \& Cerra FB (1991) Dietary omega-3 fatty acids decrease mortality and Kupffer cell prostaglandin $\mathrm{E}_{2}$ production in a rat model of chronic sepsis. Journal of Trauma 31, 768-774.

Beale RJ, Bryg DJ \& Bihari DJ (1999) Immunonutrition in the critically ill: a systematic review of clinical outcome. Critical Care Medicine 27, 2799-2805.

Berthou L, Saladin R, Yaqoob P, Branellec D, Calder P, Fruchart J-C, Denefle P, Auwerx J \& Staels B (1995) Regulation of rat liver apolipoprotein A-I, apoliporotein A-II and acyl CoA oxidase gene expression by fibrates and dietary fatty acids. European Journal of Biochemistry 232, 179-187.

Betz M \& Fox BS (1991) Prostaglandin E2 inhibits production of Th1 lymphokines but not of Th2 lymphokines. Journal of Immunology 146, 108-113.

Beutler B, Milsark IW \& Cerami AC (1985) Passive immunization against cachetin/tumor necrosis factor protects mice from lethal effect of endotoxin. Science 229, 869-871.

Billiar T, Bankey P, Svingen B, Curran RD, West MA, Holman RT, Simmons RL \& Cerra FB (1988) Fatty acid uptake and Kupffer cell function: fish oil alters eicosanoid and monokine production to endotoxin stimulation. Surgery 104, 343-349.

Black PN \& Sharp S (1997) Dietary fat and asthma: is there a connection? European Respiratory Journal 10, 6-12.

Braga M, Gianotti L, Radaelli G, Vignali A, Mari G, Gentilini O \& Di Carlo V (1999) Perioperative immunonutrition in patients undergoing cancer surgery. Archives of Surgery 134, 428-433.

Braga M, Vignali A, Gianotti L, Cestari A, Profili M \& Di Carlo V (1996) Immune and nutritional effects of early enternal nutrition after major abdominal operations. European Journal of Surgery 162, 105-112.

Breil I, Koch T, Heller A, Schlotzer E, Grunert A, van Ackern K \& Neuhof H (1996) Alteration of $n-3$ fatty acid composition in lung tissue after short-term infusion of fish oil emulsion attenuates inflammatory vascular reaction. Critical Care Medicine 24, 1893-1902.

Breittmayer J-P, Pelassy C, Cousin J-L, Bernard A \& Aussel C (1993) The inhibition by fatty acids of receptor-mediated calcium movements in Jurkat T-cells is due to increased calcium extrusion. Journal of Biological Chemistry 268, 20812-20817.

Broughton KS, Johnson CS, Pace BK, Liebman M \& Kleppinger KM (1997) Reduced asthma symptoms with $n$-3 fatty acid ingestion are related to 5-series leukotriene production. American Journal of Clinical Nutrition 65, 1011-1017.

Calder PC (1997) N-3 polyunsaturated fatty acids and cytokine production in health and disease. Annals of Nutrition and Metabolism 41, 203-234.

Calder PC (1998) N-3 fatty acids and mononuclear phagocyte function. In Medicinal Fatty Acids in Inflammation, pp. 1-27 [JM Kremer, editor]. Basel: Birkhauser Verlag.

Calder PC (2001a) n-3 Polyunsaturated fatty acids, inflammation and immunity: pouring oil on troubled waters or another fishy tale? Nutrition Research 21, 309-341. 
Calder PC (2001b) N-3 Fatty acids and rheumatoid arthritis. In Food and Nutritional Supplements in Health and Disease, pp. 175-197 [JK Ransley, JK Donnelly and NW Read, editors]. London: Springer Verlag.

Calder PC, Bond JA, Harvey DJ, Gordon S \& Newsholme EA (1990) Uptake of saturated and unsaturated fatty acids into macrophage lipids and their effect upon macrophage adhesion and phagocytosis. Biochemical Journal 269, 807-814.

Calder PC \& Miles EA (2000) Fatty acids and atopic disease. Pediatric Allergy and Immunology 11 Suppl., 29-36.

Calder PC \& Zurier RB (2001) Polyunsaturated fatty acids and rheumatoid arthritis. Current Opinion in Clinical Nutrition and Metabolic Care 4, 115-121.

Cannon JG, Tompkins RG, Gelfrand JA, Michie HR, Stanford GG, Van der Meer JW, Endres S, Lonnemann G, Corsetti J, Chernow B, Wilmore DW, Wolff SM, Burke JF \& Dinarello CA (1990) Circulating interleukin-1 and tumor necrosis factor in septic shock and experimental endotoxin fever. Journal of Infectious Disease 161, 79-84.

Caughey GE, Mantzioris E, Gibson RA, Cleland LG \& James MJ (1996) The effect on human tumor necrosis factor $\alpha$ and interleukin $1 \beta$ production of diets enriched in $n-3$ fatty acids from vegetable oil or fish oil. American Journal of Clinical Nutrition 63, 116-122.

Chandrasekar B \& Fernandes G (1994) Decreased pro-inflammatory cytokines and increased antioxidant enzyme gene expression by $\omega-3$ lipids in murine lupus nephritis. Biochemical and Biophysical Research Communications 200, 893-898.

Chen F, Castranova V, Shi X \& Demers LM (1999) New insights into the role of nuclear factor- $\mathrm{\kappa B}$, a ubiquitous transcription factor in the initiation of diseases. Clinical Chemistry $\mathbf{4 5}$, 7-17.

Chen LH \& Zhao Y (2001) Eicosapentaenoic acid decreases lipopolysaccharide-stimulated tumor necrosis factor-alpha expression by inhibiting nuclear factor kappa B activation. FASEB Journal 15, A258.

Chinetti G, Fruchart JC \& Staels B (2000) Peroxisome proliferatoractivated receptors (PPARs): nuclear receptors at the crossroads between lipid metabolism and inflammation. Inflammation Research 49, 497-505.

Chinetti G, Griglio S, Antonucci M, Torra IP, Delerive P, Majd Z, Fruchart JC, Chapman J, Najib J \& Staels B (1998) Activation of peroxisome-activated receptors alpha and gamma induces apoptosis of human monocyte-derived macrophages. Journal of Biological Chemistry 273, 25573-25580.

Chow SC, Ansotegui IJ \& Jondal M (1990) Inhibition of receptormediated calcium influx in T cells by unsaturated non-esterified fatty acids. Biochemical Journal 267, 727-732.

Christman JW, Lancaster LH \& Blackwell TS (1998) Nuclear factor- $\mathrm{\kappa B}$ : a pivotal role in systemic inflammatory response syndrome and new target for therapy. Intensive Care Medicine 24, 1131-1138.

Chu AJ, Walton MA, Prasad JK \& Seto A (1999) Blockade by polyunsaturated $n-3$ fatty acids of endotoxin-induced monocytic tissue factor activation is mediated by the depressed receptor expression in THP-1 cells. Journal of Surgical Research 87, 217-224.

Cleland LG \& James MJ (2000) Fish oil and rheumatoid arthritis: antiinflammatory and collateral health benefits. Journal of Rheumatology 27, 2305-2307.

Curtis CL, Hughes CE, Flannery CR, Little CB, Harwood JL \& Caterson B (2000) n-3 Fatty acids specifically modulate catabolic factors involved in articular cartilage degradation. Journal of Biological Chemistry 275, 721-724.

De Caterina R, Cybulsky MI, Clinton SK, Gimbrone MA \& Libby P (1994) The omega-3 fatty acid docosahexaenoate reduces cytokine-induced expression of proatherogenic and proinflammatory proteins in human endothelial cells. Arteriosclerosis and Thrombosis 14, 1829-1836.

De Caterina R \& Libby P (1996) Control of endothelial leukocyte adhesion molecules by fatty acids. Lipids 31, S57-S63.

Delerive P, Fruchart JC \& Staels B (2001) Peroxisome proliferatoractivated receptors in inflammation control. Journal of Endocrinology 169, 453-459.

Devchand PR, Keller H, Peters JM, Vazquez M, Gonzalez FJ \& Wahli W (1996) The PPAR $\alpha$-leukotriene B4 pathway to inflammation control. Nature 384, 39-43.

Donnellan CE, Tadayyon M, Briscoe C, Arch J \& Calder PC (2000) The effect of dietary fatty acids on the expression of genes involved in lipid handling. Proceedings of the Nutrition Society 59, $111 \mathrm{~A}$.

Dunder T, Kuikka L, Turtinen J, Rasanen L \& Uhari M (2001) Diet, serum fatty acids, and atopic diseases in childhood. Allergy $\mathbf{5 6}$, $425-428$.

Endres S, Ghorbani R, Kelley VE, Georgilis K, Lonnemann G, van der Meer JMW, Cannon JG, Rogers TS, Klempner MS, Weber PC, Schaeffer EJ, Wolff SM \& Dinarello CA (1989) The effect of dietary supplementation with $n-3$ polyunsaturated fatty acids on the synthesis of interleukin- 1 and tumor necrosis factor by mononuclear cells. New England Journal of Medicine 320, $265-271$.

Ertel W, Morrison MH, Meldrum DR, Ayala A \& Chaudry IH (1992) Ibuprofen restores cellular immunity and decreases susceptibility to sepsis following hemorrhage. Journal of Surgical Research 53, 55-61.

Faull RJ (1995) Adhesion molecules in health and disease. Australian and New Zealand Journal of Medicine 25, 720-730.

Feldmann M, Brennan FM \& Maini RN (1996) Role of cytokines in rheumatoid arthritis. Annual Review of Immunology 14, 397-440.

Feldmann M \& Maini RN (1999) The role of cytokines in the pathogenesis of rheumatoid arthritis. Rheumatology 38, Suppl. 2, 3-7.

Gadek JE, DeMichele SJ, Karlstad MD, Pacht ER, Donahoe M, Albertson TE, Van Hoozen C, Wennberg AK, Nelson J, Noursalehi M \& the Enteral Nutrition in ARDS Study Group (1999) Effect of enteral feeding with eicosapentaenoic acid, $\gamma$ linolenic acid, and antioxidants in patients with acute respiratory distress syndrome. Critical Care Medicine 27, 1409-1420.

Gallai V, Sarchielli P, Trequattrini A, Franceschini M, Floridi A, Firenze C, Alberti A, Di Benedetto D \& Stragliotto E (1993) Cytokine secretion and eicosanoid production in the peripheral blood mononuclear cells of MS patients undergoing dietary supplementation with $n-3$ polyunsaturated fatty acids. Journal of Neuroimmunology 56, 143-153.

Geusens PP (1998) $n$-3 Fatty acids in the treatment of rheumatoid arthritis. In Medicinal Fatty Acids in Inflammation, pp. 111-123 [JM Kremer, editor]. Basel: Birkhauser Verlag.

Gianotti L, Braga M, Fortis C, Soldini L, Vignali A, Colombo S, Radaelli G \& Di Carlo V (1999) A prospective, randomised clinical trial on perioperative feeding with an arginine-, omega-3 fatty acid-, and RNA-enriched enteral diet: effect on host response and nutritional status. Journal of Parenteral and Enteral Nutrition 23, 314-320.

Gibney MJ \& Hunter B (1993) The effects of short- and long-term supplementation with fish oil on the incorporation of $n-3$ polyunsaturated fatty acids into cells of the immune system in healthy volunteers. European Journal of Clinical Nutrition 47, 255-259.

Gold KN, Weyand CM \& Goronzy JJ (1994) Modulation of helper T cell function by prostaglandins. Arthritis and Rheumatism 37, 925-933.

Grbic JT, Mannick JA, Gough DB \& Rodrick ML (1991) The role of prostaglandin $E_{2}$ in immune suppression following injury. Annals of Surgery 214, 253-263. 
Grimm H, Tibell A, Norrlind B, Blecher C, Wilker S \& Schwemmle K (1994) Immunoregulation by parenteral lipids: impact of the $n-3$ to $n-6$ fatty acid ratio. Journal of Parenteral and Enteral Nutrition 18, 417-421.

Grimminger F, Wahn H, Kramer HJ, Stevens J, Mayer K, Walmrath D \& Seeger W (1995) Differential influence of arachidonic acid vs. eicosapentaenoic acid on experimental pulmonary-hypertension. American Journal of Physiology 268, H2252-H2259.

Grimminger F, Wahn H, Mayer K, Kiss L, Walmrath D \& Seeger W (1997) Impact of arachidonic acid versus eicosapentaenoic acid on exotoxin-induced lung vascular leakage - relation to 4series versus 5-series leukotriene generation. American Journal of Respiratory and Critical Care Medicine 155, 513-519.

Hayashi N, Tashiro T, Yamamori H, Takagi K, Morishima Y, Otsubo Y, Sugiura T, Furukawa K, Nitta H, Nakajima N, Suzuki N \& Ito I (1998) Effects of intravenous omega-3 and omega-6 fat emulsion on cytokine production and delayed type hypersensitivity in burned rats receiving total parenteral nutrition. Journal of Parenteral and Enteral Nutrition 22, 363-367.

Hellerstein MK, Meydani SN, Meydani M, Wu K \& Dinarello CA (1989) Interleukin-1-induced anorexia in the rat: influence of prostaglandins. Journal of Clinical Investigation 84, 228-235.

Henderson WR (1994) Role of leukotrienes in asthma. Annals of Allergy 72, 272-278.

Hodge L, Peat JK \& Salome C (1994) Increased consumption of polyunsaturated oils may be a cause of increased prevalence of childhood asthma. Australian and New Zealand Journal of Medicine 24, 727.

Hughes DA, Pinder AC, Piper Z, Johnson IT \& Lund EK (1996a) Fish oil supplementation inhibits the expression of major histocompatibility complex class II molecules and adhesion molecules on human monocytes. American Journal of Clinical Nutrition 63, 267-272.

Hughes DA, Southon S \& Pinder AC (1996b) (n-3) Polyunsaturated fatty acids modulate the expression of functionally associated molecules on human monocytes in vitro. Journal of Nutrition 126, 603-610.

Hwang D \& Rhee SH (1999) Receptor-mediated signaling pathways: potential targets of modulation by dietary fatty acids. American Journal of Clinical Nutrition 70, 545-556.

Jackson SM, Parhami F, Xi X-P, Berliner JA, Hsueh WA, Law RE \& Demer LL (1999) Peroxisome proliferator-activated receptor activators target human endothelial cells to inhibit leukocyteendothelial cell interaction. Arteriosclerosis Thrombosis and Vascular Biology 19, 2094-2104.

James MJ \& Cleland LG (1997) Dietary $n$-3 fatty acids and therapy for rheumatoid arthritis. Seminars in Arthritis and Rheumatism 27, 85-97.

Jiang CY, Ting AT \& Seed B (1998) PPAR-gamma agonists inhibit production of monocyte inflammatory cytokines. Nature 391, 82-86.

Jolly CA, Jiang Y-H, Chapkin RS \& McMurray DN (1997) Dietary $(n-3)$ polyunsaturated fatty acids suppress murine lymphoproliferation, interleukin-2 secretion and the formation of diacylglycerol and ceramide. Journal of Nutrition 127, 37-43.

Kamochi M, Kamochi F, Kim YB, Sawh S, Sanders JM, Sarembock I, Green S, Young JS, Ley K, Fu SM \& Rose CE (1999) P-selectin and ICAM-1 mediate endotoxin-induced neutrophil recruitment and injury to the lung and liver. American Journal of Physiology 277, L310-L319.

Karin M \& Ben-Neriah Y (2000) Phosphorylation meets ubiquination: the control of NF-kappaB activity. Annual Review of Immunology 18, 621-663.

Karin M \& Delhase M (2000) The I kappa B kinase (IKK) and NFkappa B: key elements of proinflammatory signalling. Seminars in Immunology 12, 85-98.
Khair-El-Din T, Sicher SC, Vazquez MA, Chung GW, Stallwort KA, Kitamura K, Miller RT \& Lu CY (1996) Transcription of the murine iNOS gene is inhibited by docosahexaenoic acid, a major constituent of fetal and neonatal sera as well as fish oils. Journal of Experimental Medicine 183, 1241-1246.

Khalfoun B, Thibault G, Bardos P \& Lebranchu Y (1996) Docosahexaenoic and eicosapentaenoic acids inhibit in vitro human lymphocyte-endothelial cell adhesion. Transplantation 62, 1649-1657.

Khalfoun B, Thibault F, Watier H, Bardos P \& Lebranchu Y (1997) Docosahexaenoic and eicosapentaenoic acids inhibit in vitro human endothelial cell production of interleukin-6. Advances in Experimental Biology and Medicine 400, 589-597.

Kim DN, Schmee J \& Thomas WA (1995) Dietary fish oil added to a hyperlipidemic diet for swine results in reduction in the excessive number of monocytes attached to the arterial endothelium. Atherosclerosis 81, 209-216.

Kinsella JE, Lokesh B, Broughton S \& Whelan J (1990) Dietary polyunsaturated fatty acids and eicosanoids: potential effects on the modulation of inflammatory and immune cells: An overview. Nutrition 6, 24-44.

Kliewer SA, Lenhard JM, Willson TM, Patel I, Morris DC \& Lehman JM (1995) A prostaglandin J2 metabolite binds peroxisome proliferator-activated receptor $\gamma$ and promotes adipocyte differentiation. Cell 83, 813-819.

Knapp HR (1995) Omega-3 fatty-acids in respiratory diseases - A review. Journal of the American College of Nutrition 14, 18-23.

Kremer JM, Lawrence DA, Jubiz W, Di Giacomo R, Rynes K, Bartholomew LE \& Sherman M (1990) Dietary fish oil and olive oil supplementation in patients with rheumatoid arthritis. Arthritis and Rheumatism 33, 810-820.

Kumasaka T, Quinlan WM, Doyle NA, Condon NA, Sligh J, Takei F, Beaudet AL, Bennett CF \& Doerschuk CM (1996) Role of intercellular adhesion molecule-1 (ICAM-1) in endotoxininduced pneumonia evaluated using ICAM- 1 antisense oligonucleotides, anti-ICAM-1 monoclonal antibodies, and ICAM-1 mutant mice. Journal of Clinical Investigation 97, 2362-2369.

Lanza-Jacoby S, Flynn JT \& Miller S (2001) Parenteral supplementation with a fish oil emulsion prolongs survival and improves lymphocyte function during sepsis. Nutrition 17, 112-116.

Lee TH, Hoover RL, Williams JD, Sperling RI, Ravalese J, Spur BW, Robinson DR, Corey EJ, Lewis RA \& Austen KF (1985) Effects of dietary enrichment with eicosapentaenoic acid and docosahexaenoic acid on in vitro neutrophil and monocyte leukotriene generation and neutrophil function. New England Journal of Medicine 312, 1217-1224.

Leslie CA, Gonnerman WA, Ullman MD, Hayes KC, Franzblau C \& Cathcart ES (1985) Dietary fish oil modulates macrophage fatty acids and decreases arthritis susceptibility in mice. Journal of Experimental Medicine 162, 1336-1349.

Lewis RA, Austen KF \& Soberman RJ (1990) Leukotrienes and other products of the 5-lipoxygenase pathway: Biochemistry and relation to pathobiology in human diseases. New England Journal of Medicine 323, 645-655.

Lo CJ, Chiu KC, Fu MJ, Chu A \& Helton S (2000) Fish oil modulates macrophage P44/42 mitogen-activated protein kinase activity induced by lipopolysaccharide. Journal of Parenteral and Enteral Nutrition 24, 159-163.

McCabe AJ, Wallace J, Gilmore W, Strain JJ \& McGlynn H (1999) The effect of eicosapentaenoic acid on matrix metalloproteinase gene expression. Lipids 34, S217-S218.

McCann ME, Moore JN, Carrick JB \& Barton MH (2000) Effect of intravenous infusion of omega- 3 and omega- 6 lipid emulsions on equine monocyte fatty acid composition and inflammatory mediator production in vitro. Shock 14, 222-228.

Marx N, Sukhova GK, Collins T, Libby P \& Plutzky J (1999) PPAR $\alpha$ activators inhibit cytokine-induced vascular cell 
adhesion molecule-1 expression in human endothelial cells. Circulation 99, 3125-3131.

Mascioli EA, Iwasa Y, Trimbo S, Leader L, Bistrian BR \& Blackburn GL (1989) Endotoxin challenge after menhaden oil diet: effects on survival of guinea pigs. American Journal of Clinical Nutrition 49, 277-282.

Mascioli EA, Leader L, Flores E, Trimbo S, Bistrian B \& Blackburn G (1988) Enhanced survival to endotoxin in guinea pigs fed iv fish oil emulsion. Lipids 23, 623-625.

Mathison JC, Wolfson E \& Ulevitch RJ (1988) Participation of tumor necrosis factor in the mediation of Gram negative bacterial lipopolysaccharide-induced injury in rabbits. Journal of Clinical Investigation 81, 1925-1937.

May CL, Southwoth AJ \& Calder PC (1993) Inhibition of lymphocyte protein kinase $\mathrm{C}$ by unsaturated fatty acids. Biochemical and Biophysical Research Communications 195, 823-828.

Meydani SN, Endres S, Woods MM, Goldin BR, Soo C, MorrillLabrode A, Dinarello C \& Gorbach SL (1991) Oral (n-3) fatty acid supplementation suppresses cytokine production and lymphocyte proliferation: comparison between young and older women. Journal of Nutrition 121, 547-555.

Meydani SN, Lichtenstein AH, Cornwall S, Meydani M, Goldin BR, Rasmussen H, Dinarello CA \& Schaefer EJ (1993) Immunologic effects of national cholesterol education panel step-2 diets with and without fish-derived $n-3$ fatty acid enrichment. Journal of Clinical Investigation 92, 105-113.

Miles EA, Thies F, Wallace FA, Powell JR, Hirst TL, Newsholme EA \& Calder PC (2001) Influence of age and dietary fish oil on plasma soluble adhesion molecule concentrations. Clinical Science 100, 91-100.

Miles EA, Wallace FA \& Calder PC (2000) Dietary fish oil reduces intercellular adhesion molecule 1 and scavenger receptor expression on murine macrophages. Atherosclerosis 152, 43-50.

Mulrooney HM \& Grimble RF (1993) Influence of butter and of corn, coconut and fish oils on the effects of recombinant human tumour necrosis factor- $\alpha$ in rats. Clinical Science 84, $105-112$.

Obata T, Nagakura T, Masaki T, Maekawa K \& Yamashita K (1999) Eicosapentaenoic acid inhibits prostaglandin D2 generation by inhibiting cyclo-oxygenase- 2 in cultured human mast cells. Clinical and Experimental Allergy 29, 1129-1135.

Okusawa S, Gelfrand JA, Ikejima T, Connolly RJ \& Dinarello CA (1988) Interleukin 1 induces a shock-like state in rabbits. Synergism with tumor necrosis factor and effect of cyclooxygenase inhibition. Journal of Clinical Investigation 81, $1162-1172$.

Panayi GS (1999) Targetting of cells involved in the pathogenesis of rheumatoid arthritis. Rheumatology 38 Suppl. 2, 8-10.

Pfeffer K, Matsuyama T, Kundig TM, Wakeham A, Kishihara K, Shahinlan A, Wiegmann K, Ohashi PS, Kronke M \& Mak TW (1993) Mice deficient for the $55 \mathrm{kd}$ tumor necrosis factor receptor are resistant to endotoxic shock, yet succumb to $L$. monocytogenes infection. Cell 73, 457-467.

Pomposelli J, Mascioli EA, Bistrian BR \& Flores SM (1990) Attenuation of the febrile response in guinea pigs by fish oil enriched diets. Journal of Parenteral and Enteral Nutrition 13, 136-140.

Poynter ME \& Daynes RA (1998) Peroxisome proliferatoractivated receptor alpha activation modulates cellular redox status, represses nuclear factor kappa B signalling, and reduces inflammatory cytokine production in aging. Journal of Biological Chemistry 273, 32833-32841.

Pscheidl E, Schywalsky M, Tschaikowsky K \& Boke-Prols T (2000) Fish oil-supplemented parenteral diets normalize splanchnic blood flow and improve killing of translocated bacteria in a low-dose endotoxin rat model. Critical Care Medicine 28, 1489-1496.

Raeburn CD, Calkins CM, Zimmerman MA, Song Y, Ao LH, Banerjee A, Meng XZ \& Harken AH (2001) Vascular cell adhesion molecule-1 expression is obligatory for endotoxininduced myocardial neutrophil accumulation and contractile dysfunction. Surgery 130, 319-325.

Rayon JI, Carver JD, Wyble LE, Wiener D, Dickey SS, Benford VJ, Chen LT \& Lim DV (1997) The fatty acid composition of maternal diet affects lung prostaglandin $\mathrm{E}_{2}$ levels and survival from group B Streptococcal sepsis in neonatal rat pups. Journal of Nutrition 127, 1989-1992.

Renier G, Skamene E, de Sanctis J \& Radzioch D (1993) Dietary $n-3$ polyunsaturated fatty acids prevent the development of atherosclerotic lesions in mice: Modulation of macrophage secretory activities. Arteriosclerosis and Thombosis 13, 1515-1524.

Ricote M, Li AC, Willson TM, Kelly CJ \& Glass CK (1998) The peroxisome proliferator-activated receptor-gamma is a negative regulator of macrophage activation. Nature 391, 79-82.

Robinson DR, Urakaze M, Huang R, Taki H, Sugiyama E, Knoell CT, Xu L, Yeh ETH \& Auron PE (1996) Dietary marine lipids suppress continuous expression on interleukin-1 $\beta$ gene expression. Lipids 31, S23-S31.

Rola-Pleszczynski M \& Stankova J (1992) Cytokine gene regulation by PGE2, LTB4 and PAF. Mediators of Inflammation $1,5-8$.

Ross JA, Moses AGW \& Fearon KCH (1999) The anti-catabolic effects of $n-3$ fatty acids. Current Opinion in Clinical Nutrition and Metabolic Care 2, 219-226.

Sadeghi S, Wallace FA \& Calder PC (1999) Dietary lipids modify the cytokine response to bacterial lipopolysaccharide in mice. Immunology 96, 404-410.

Sanderson P \& Calder PC (1998a) Dietary fish oil diminishes lymphocyte adhesion to macrophage and endothelial cell monolayers. Immunology 94, 79-87.

Sanderson P \& Calder PC (1998b) Dietary fish oil appears to inhibit the activation of phospholipase C- $\gamma$ in lymphocytes. Biochimica et Biophysica Acta 1392, 300-308.

Sanderson P, Yaqoob P \& Calder PC (1995a) Effects of dietary lipid manipulation upon rat spleen lymphocyte functions and the expression of lymphocyte surface molecules. Journal of Nutritional and Environmental Medicine 5, 119-132.

Sanderson P, Yaqoob P \& Calder PC (1995b) Effects of dietary lipid manipulation upon graft vs. host and host vs. graft responses in the rat. Cellular Immunology 164, 240-247.

Sano H, Hla T, Maier JAM, Crofford LJ, Case JP, Maciag T \& Wilder RL (1992) In vivo cyclooxygenase expression in synovial tissues of patients with rheumatoid arthritis and osteoarthritis and rats with adjuvant and streptococcal cell wall arthritis. Journal of Clinical Investigation 89, 97-108.

Sasaki T, Kanke Y, Kudoh K, Nagahashi M, Toyokawa M, Matsuda M, Shimizu J \& Takita T (2000) Dietary $n$-3 polyunsaturated fatty acid and status of immunocompetent cells involved in innate immunity in female rats. Annals of Nutrition and Metabolism 44, 38-42.

Schoonjans K, Staels B \& Auwerx J (1996) The peroxisome proliferator activated receptors (PPARs) and their effects on lipid metabolism and adipocyte differentiation. Biochimica et Biophysica Acta 1302, 93-109.

Schulzki C, Mertes N, Wenn A, Goeters C, Grimm H, Schlotzer E, Spindler A, Gokorsch S, Mayer K, Grimminger F, Seeger W, Kuhn KS \& Furst P (1999) Effects of a new type of lipid emulsion based on soybean oil, MCT, olive oil and fish oil (SMOF) in surgical patients. Clinical Nutrition 18 Suppl. 1, 7. 
Sinha B, Stoll D, Weber PC \& Endres S (1991) Polyunsaturated fatty acids modulate the synthesis of TNF- $\alpha$ and interleukin- $1 \beta$ by human mononuclear cells in vitro. Cytokine 3, 475.

Snijdewint FGM, Kalinski P, Wieringa EA, Bos JD \& Kapsenberg ML (1993) Prostaglandin $E_{2}$ differentially modulates cytokine secretion profiles in human T-helper lymphocytes. Journal of Immunology 150, 5321-5329.

Sperling RI (1995) Eicosanoids in rheumatoid arthritis. Rheumatological Disease Clinics of North America 21, 741-758.

Sperling RI, Benincaso AI, Knoell CT, Larkin JK, Austen KF \& Robinson DR (1993) Dietary $\omega-3$ polyunsaturated fatty acids inhibit phosphoinositide formation and chemotaxis in neutrophils. Journal of Clinical Investigation 91, 651-660.

Takano H, Nagai T, Asakawa M, Toyozaki T, Oka T, Komuro I, Saito T \& Masuda Y (2000) Peroxisome proliferator-receptor activators inhibit lipopolysaccharide-induced tumor necrosis factor-alpha expression in neonatal rat cardiac myocytes. Circulation Research 87, 596-602.

Tang WW, Yi ES, Remick DG, Wittwer A, Yin SM, Qi MY \& Ulich TR (1995) Intratracheal injection of endotoxin and cytokines. 9. Contribution of CD11a/ICAM-1 to neutrophil emigration. American Journal of Physiology 269, L653-L659.

Tappia PS, Man WJ \& Grimble RF (1995) Influence of unsaturated fatty acids on the production of tumour necrosis factor and interleukin- 6 by rat peritoneal macrophages. Molecular and Cellular Biochemistry 143, 89-98.

Tashiro T, Yamamori H, Takagi K, Hayashi N, Furukawa K \& Nakajima $\mathrm{N}$ (1998) $n$-3 versus $n-6$ polyunsaturated fatty acids in critical illness. Nutrition 14, 551-553.

Tepaske R, te Velthuis H, Oudemans-van Straaten M, Heisterkamp SH, van Deventer SJH, Ince C, Eysman L \& Keseciogu J (2001) Effect of preoperative oral immune-enhancing nutritional supplement on patients at risk of infection after cardiac surgery: a randomised placebo-controlled trial. Lancet 358, 696-701.

Thies F, Nebe-von-Caron G, Powell JR, Yaqoob P, Newsholme EA \& Calder PC (2001) Dietary supplementation with $\gamma$-linolenic acid or with fish oil decreases $\mathrm{T}$ lymphocyte proliferation in healthy older humans. Journal of Nutrition 131, 1918-1927.

Thomas LT (1972) Notes of a biology-watcher. New England Journal of Medicine 287, 553-555.

Tilley SL, Coffman TM \& Koller BH (2001) Mixed messages: modulation of inflammation and immune responses by prostaglandins and thromboxanes. Journal of Clinical Investigation 108, 15-23.

Tracey KJ, Beutler B, Lowry SF, Merryweather J, Wolpe S, Milsark IW, Hariri RJ, Fahey TJ, Zentella A, Albert JD, Shires GT \& Cerami A (1986) Shock and tissue injury induced by recombinant human cachectin. Science 234, 470-474.

Tracey KJ, Fong Y, Hesse DG, Manogue KR, Lee AT, Kuo GC, Lowry SF \& Cerami AC (1987) Anti-cachectin/TNF monoclonal antibodies prevent septic shock during lethal bacteraemia. Nature 330, 662-664.
Vervloet MG, Thijs LG \& Hack CE (1998) Derangements of coagulation and fibrinoloysis in critically ill patients with sepsis and septic shock. Seminars in Thrombosis and Hemostasis 24 33-44.

Volker DH, FitzGerald PEB \& Garg ML (2000) The eicosapentaenoic to docosahexaenoic acid ratio of diets affects the pathogenesis of arthritis in Lew/SSN rats. Journal of Nutrition 130, 559-565.

Volker D \& Garg M (1996) Dietary $n-3$ fatty acid supplementation in rheumatoid arthritis - mechanisms, clinical outcomes, controversies, and future directions. Journal of Clinical and Biochemical Nutrition 20, 83-97.

Wachtler P, Konig W, Senkal M, Kemen M \& Koller M (1997) Influence of a total parenteral nutrition enriched with $\omega-3$ fatty acids on leukotriene synthesis of peripheral leukocytes and systemic cytokine levels in patients with major surgery. Journal of Trauma 42, 191-198.

Wallace FA, Miles EA \& Calder PC (2000) Activation state alters the effect of dietary lipids on pro-inflammatory mediator production by murine macrophages. Cytokine 12, 1374-1379.

Wallace FA, Miles EA, Evans C, Stock TE, Yaqoob P \& Calder PC (2001) Dietary fatty acids influence the production of Th1-but not Th2-type cytokines. Journal of Leukocyte Biology 69, 449-457.

Wang P, Anderson PO, Chen SW, Paulsson KM, Sjogren HO \& Li SL (2001) Inhibition of the transcription factors AP-1 and NF-kappa B in CD4 T cells by peroxisome proliferator-activated receptor gamma ligands. International Immunopharmacology $\mathbf{1}$, 803-812.

Wu GH, Zhang YW \& Wu ZH (2001) Modulation of postoperative immune and inflammatory response by immune-enhancing enteral diet in gastrointestinal cancer patients. World Review of Gastroenterology 7, 357-362.

Xi S, Cohen D, Barve S \& Chen LH (2001) Fish oil suppressed cytokines and nuclear factor kappaB induced by murine AIDS virus infection. Nutrition Research 21, 865-878.

Xi S, Cohen D \& Chen LH (1998) Effects of fish oil on cytokines and immune functions of mice with murine AIDS. Journal of Lipid Research 39, 1677-1687.

Xu X, Otsuki M, Saito H, Sumitani S, Yamamoto H, Asanuma N, Kouhara H \& Kasayama S (2001) PPAR alpha and GR differentially down-regulate the expression of nuclear factor-kappa B-responsive genes in vascular endothelial cells. Endocrinology 142, 3332-3339.

Yaqoob P \& Calder PC (1995) Effects of dietary lipid manipulation upon inflammatory mediator production by murine macrophages. Cellular Immunology 163, 120-128.

Yaqoob P, Pala HS, Cortina-Borja M, Newsholme EA \& Calder PC (2000) Encapsulated fish oil enriched in $\alpha$-tocopherol alters plasma phospholipid and mononuclear cell fatty acid compositions but not mononuclear cell functions. European Journal of Clinical Investigation 30, 260-274. 